\title{
Standardization of Blending of Guava Pulp with Pineapple Juice for Preparation of Ready-To-Serve (RTS)
}

\author{
Animesh Sarkar* and Jimi Bulo \\ Department of Horticulture, SASRD, Medziphema campus, Nagaland University, \\ Medziphema-797106, Nagaland, Myanmar, Burma \\ *Corresponding author
}

\begin{tabular}{|c|c|}
\hline & A B S T R A C T \\
\hline & $\begin{array}{l}\text { A laboratory experiment was conducted during the period of August to November } 2015 \text { at } \\
\text { the Department of Horticulture, SASRD, Medziphema Campus, Nagaland University to } \\
\text { standardize the blending of guava pulp (Gp) with pineapple juice (Pj) for preparation of } \\
\text { Ready-to-Serve (RTS). The experiment was composed of six treatments with four } \\
\text { replications and arranged in a complete randomized design. The treatment comprised of: } \\
\mathrm{T}_{1} 100 \%(\mathrm{Gp}), \mathrm{T}_{2}(90 \% \mathrm{Gp:} 10 \% \mathrm{Pj}), \mathrm{T}_{3}(80 \% \mathrm{Gp}: 20 \% \mathrm{Pj}), \mathrm{T}_{4}(70 \% \mathrm{Gp:} 30 \% \mathrm{Pj}), \mathrm{T}_{5} \\
(60 \% \mathrm{Gn}: 40 \% \mathrm{Pi}) \text { and } \mathrm{T}_{6}(50 \% \mathrm{Gp}: 50 \% \mathrm{Pi}) \text {. Fully ripen guava fruits cv. L-49 and } 3 / 4^{\text {th }}\end{array}$ \\
\hline $\begin{array}{l}\text { Ke y w o r d s } \\
\text { Ready-to-Serve, } \\
\text { Blending ratio, } \\
\text { Chemical } \\
\text { composition, } \\
\text { Organoleptic taste, } \\
\text { Storage. }\end{array}$ & $\begin{array}{l}\text { matured pineapple cv. Kew were collected to carry out the experiment under hygienic } \\
\text { condition in laboratory. Various chemical constituents including organoleptic evaluation } \\
\text { (adopting five expert panel with } 9 \text { point Hedonic scale) were analyzed for two and half } \\
\text { months at } 15 \text { days interval at ambient storage condition for standardization and evaluation } \\
\text { the qualitative changes and storage of best blended ratio. TSS, total sugar, non-reducing } \\
\text { sugar, TSS: acid ratio and pH increased with increased level of pineapple juice with guava } \\
\text { pulp and decreased in ascorbic acid and reducing sugar with increased level of pineapple }\end{array}$ \\
\hline Article Info & juice. In the experiment, it was found to increase in total sugar, reducing sugar, TSS, $\mathrm{pH}$ \\
\hline $\begin{array}{l}\text { Accepted: } \\
\text { 07 September } 2017 \\
\text { Available Online: } \\
\text { 10 November } 2017\end{array}$ & $\begin{array}{l}\text { and TSS: acid ratio of drinks, whereas ascorbic acid, acidity, non-reducing sugar and } \\
\text { overall acceptability gradually declined with advancement of storage period. The added } \\
50 \% \text { guava pulp and } 50 \% \text { pineapple juice improved the drink quality with special } \\
\text { reference to TSS }\left(15.54{ }^{\circ} \mathrm{B}\right) \text {, total sugar }(8.65 \%) \text { and TSS acid ratio }(49.85) \text {. But the ratio } \\
\text { of } 60 \% \text { guava pulp and } 40 \% \text { pineapple juice reached the highest sensory characters for }\end{array}$ \\
\hline & $\begin{array}{l}\text { overall acceptability ( } 7.74 \text { score out of } 9 \text { point hedonic scale) with } 15.29{ }^{\circ} \mathrm{B} \text { TSS and } \\
0.317 \% \text { acidity. Particularly in the blended beverage more emphasis is given on the basis } \\
\text { of the consumer satisfaction and overall acceptability. So in the present study, it was } \\
\text { concluded that the combination of } 60 \% \text { guava pulp and } 40 \% \text { pineapple juice was the best } \\
\text { blended ratio. }\end{array}$ \\
\hline
\end{tabular}

\section{Introduction}

Blending of two or more fruit juices in an appropriate proportion for the preparation of ready-to-serve beverage may be a convenient alternative refreshing health drink and excellent source of several important vitamins and minerals compared to synthetic beverages. The demand of synthetic beverages is several million bottles annually. If real fruit juices could be substituted for these synthetic preparations, it would be great 
for the fruit growers and consumers. There is always a demand for the consumers all over the world for new food products which should be nutritious and delicately flavoured. Moreover, owing to high acidity, astringency, bitterness and such other factors in some of the fruits, the utilization of these fruits for the preparation of various processed products becomes limited, despite having high nutritional qualities. Various workers have reported that two or more fruit juices or pulps may be blended in various proportions for the preparation of more palatable and nutritious beverages. It also enhances the appearance, nutrition, flavour of the product and lead to new product development. Fruits like guava and pineapple are most common fruits grown in subtropical condition of Nagaland and coincides each other for fruiting but due to its high perishable nature more than $80 \%$ fruit loss every year. Therefore there was an immediate requirement for processing to avoid post- harvest losses. So, keeping this in view, the present investigation was undertaken to standardize the blending proportion of guava pulp with pineapple juice and to evaluate the qualitative changes and storage of best blended ratio.

\section{Materials and Methods}

To standardize the blending of guava pulp $(\mathrm{Gp})$ with pineapple juice $(\mathrm{Pj})$ for preparation of RTS, the experiment was composed of six treatments viz. $\mathrm{T}_{1} 100 \%(\mathrm{Gp}), \mathrm{T}_{2}(90 \% \mathrm{Gp}$ : $10 \% \mathrm{Pj}), \mathrm{T}_{3}(80 \% \mathrm{Gp}: 20 \% \mathrm{Pj}), \mathrm{T}_{4}(70 \% \mathrm{Gp}:$ $30 \% \mathrm{Pj}), \mathrm{T}_{5}(60 \% \mathrm{Gp}: 40 \% \mathrm{Pj})$ and $\mathrm{T}_{6}(50 \%$ $\mathrm{Gp}: 50 \% \mathrm{Pj}$ ) with four replications and arranged in CRD. The blended beverage was analyzed in the laboratory at 15 days interval stored the products under room condition. Uniform and fully ripen blemish less guava fruits cv. L-49 and freshly $3 / 4^{\text {th }}$ matured pineapple cv. Kew were taken in the experiment. Cleaned guava fruit were sorted out and skin were peeled off. After cleaning in running water, fruits were cut into small pieces and put into a large blender jar. The guava fruit were chopped into small pieces for grinding properly. But it was not grind too much so that the seeds do not get ground and give sand like feel in the juice and sieved through double layered muslin cloth to get rid of the seed grits if there any. And it was stirred continuously with stainless steel spoon so that smooth pulp is extracted in the bowl. The well matured ripened pineapple fruits were selected and peeled with the help of stainless steel knife and the crown, rind, eyes and core was removed. Then the fruit was cut into small pieces and fed into blender for extraction of pineapple juice. The juice was strained through a double layered muslin cloth into a stainless steel container. Appropriate quantities of the extracted juice of pineapple and guava pulp of different proportion were mixed thoroughly. After that, the prepared strained syrup solution (sugar + water + acid) was added into the mixture of juice and processed upto $100{ }^{\circ} \mathrm{C}$ for 2 minutes and filled into the pre-sterilized colourless glass bottles of $200 \mathrm{ml}$ capacity and sealed air tight using crown caps with the help of a crown corking machine. The products were pasteurized in boiling water $\left(90{ }^{\circ} \mathrm{C}\right)$ for 30 min. The glass bottles were then allowed to cool down rapidly to room temperature under a fast moving ceiling fan. One set of bottles from each combination was examined immediately after preparation, both in regard to chemical and organoleptic quality. The recipe for preparation of RTS was sugar 750 $\mathrm{g}$, water $4620 \mathrm{ml}$, citric acid $16.8 \mathrm{~g}$ and KMS $0.12 \mathrm{~g}$ (Srivastava and Kumar, 1998). Before starting the experiment, initial physical and bio-chemical composition of fruit juice/pulp were measured to make the experiment more accuracy. In guava, the average fruit weight was $149.50 \mathrm{~g}$, TSS $9.39^{\circ} \mathrm{B}$, total sugar $6.94 \%$ fresh weight, acidity $0.368 \%$ fresh weight and ascorbic acid $115.48 \mathrm{mg} 100 \mathrm{~g}^{-1}$ of pulp. In pineapple, average fruit weight was $969.83 \mathrm{~g}$, 
TSS $17.82{ }^{\circ} \mathrm{B}$, total sugar $9.84 \%$ fresh weight, acidity $0.31 \%$ fresh weight and ascorbic acid10.8 mg $100 \mathrm{~g}^{-1}$ of pulp. Biochemical attributes like TSS, total sugar, acidity, Vit-C, juice $\mathrm{p}^{\mathrm{H}}$ and TSS: acid ratio of juice were estimated under the investigation.

Total soluble solids (TSS) were determined with the help of hand refractometer calibrated in ${ }^{0} \mathrm{Brix}$ at $20{ }^{0} \mathrm{C}$ with necessary correction factor. Total sugar were estimated by standard procedure of A.O.A.C. (Anon, 1984) using Fehling's A and Fehling's B reagents with methylene blue as an indicator through copper reduction method. Total titratable acidity was determined by titrating the juice against N/10 $\mathrm{NaOH}$ using phenolphthalein as indicator and expressed in percentage. 2, 6- dichlorophenol indophenol dye titration method was used to estimate the ascorbic acid content of juice and expressed as mg $100 \mathrm{ml}^{-1}$ of juice. The electronic $\mathrm{pH}$ meter was calibrated using $7 \mathrm{pH}$ and $4 \mathrm{pH}$ standard buffer solutions. The function selector switch was set to $\mathrm{pH}$ and reading of digital display was allowed to stabilize. The sensory evaluation was carried out by using 9 point hedonic scale consisting of a panel of five semi trained judges (Amerine et al., 1965).

\section{Results and Discussion}

Among the different treatment, the added $50 \%$ guava pulp and $50 \%$ pineapple juice improved the drink quality with special reference to TSS $\left(15.54{ }^{\circ} \mathrm{B}\right)$ which was followed by $\mathrm{T} 5(60 \% \mathrm{Gp}+40 \% \mathrm{Pj})$ with 15.29 ${ }^{0} \mathrm{~B}$ TSS. The total soluble solids content in the RTS increased apparently with gradual passage of storage time which might be due to hydrolysis of insoluble polysaccharides and organic acids into sugars. These results were also inconformity with Deka et al., (2005) in mango-pineapple RTS beverages stored in white and amber coloured bottles for 6 months. It was also found to gradual increase in TSS by storage period in aonla and guava blended RTS (Kumar and Godara, 2011)

The total sugar content of the guavapineapple blended RTS beverage had increased gradually with increment of pineapple juice from initial stage viz. $\mathrm{T}_{1}$ (6.47\%), $\mathrm{T}_{2}(6.72 \%), \mathrm{T}_{3}(7.40 \%), \mathrm{T}_{4}(7.86 \%)$, $\mathrm{T}_{5}(8.01 \%)$ and $\mathrm{T}_{6}(8.25 \%)$ and at the end of the storage, it was found in $\mathrm{T}_{1}(7.53 \%), \mathrm{T}_{2}$ (7.80\%), $\mathrm{T}_{3}(8.39 \%), \mathrm{T}_{4}(8.41 \%), \mathrm{T}_{5}(8.50 \%)$ and $\mathrm{T}_{6}(8.88 \%)$. The highest total sugar content was found in $\mathrm{T}_{6}(50 \% \mathrm{Gp}: 50 \% \mathrm{Pj})$ with $8.65 \%$ followed by $\mathrm{T}_{5}$ with $8.32 \%$. The increase in total sugar is might be due to the hydrolysis of polysaccharides like pectin, cellulose, starch etc. and its conversion into simple sugars like glucose and fructose reported by Sindumathi and Premalatha (2013) in the study of papaya and pineapple juice using ginger and cardamom as flavouring agents.

It was observed that there was a significant decrease in titratable acidity content in guavapineapple blended RTS beverage during storage. Initially acidity was observed as $\mathrm{T}_{1}$ (0.378\%), $\mathrm{T}_{2}(0.375 \%), \mathrm{T}_{3}(0.365 \%), \mathrm{T}_{4}$ $(0.363 \%) \mathrm{T}_{5}(0.361 \%)$ and $\mathrm{T}_{6}(0.368 \%)$ which showed the final decrease to $\mathrm{T}_{1}(0.317 \%), \mathrm{T}_{2}$ $(0.276 \%), \mathrm{T}_{3}(0.279 \%), \mathrm{T}_{4}(0.280 \%), \mathrm{T}_{5}$ $(0.275 \%)$ and $\mathrm{T}_{6}(0.260 \%)$ respectively on $75^{\text {th }}$ day of storage. But the results of storage at day of 0 and day of 75 did not show significant variation among the treatments during storage. The lowest average titratable acidity was noticed in treatment $\mathrm{T}_{6}(0.316 \%)$ followed by $\mathrm{T}_{5}(0.317 \%)$. However there was a significant decrease in titrable acidity on day $15,30,45$ and 60 during storage period in all the treatments. And the decrease in titrable acidity might be attributed to the bioconversion of acids into sugars or it could be attributed to the chemical interaction between the organic constituents of the juice induced by the temperature and action of 
enzymes (particularly invertase). Salari et al., (2012) also noticed to gradual decrease in acidity in muskmelon RTS blended with pomegranate juice. The gradual decrease in acidity was in corresponding increase in $\mathrm{pH}$ reported by Patil et al., (2014) to develop RTS by blending rose apple and jamun in different proportions.

A marginal decrease in ascorbic acid content in blended juice was found apparently with the advancement of storage during the entire period. There was successive decline in the ascorbic acid content with the increased ratio of pineapple juice concentration. The average ascorbic acid content in juices was found to

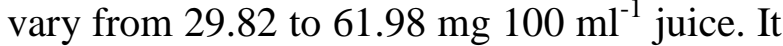
was noticed that ascorbic acid content was maximum in $\mathrm{T}_{1}$ at initial stage $(65.75 \mathrm{mg} 100$ $\mathrm{ml}^{-1}$ juice) which was found to decrease in $59.55 \mathrm{mg} 100 \mathrm{ml}^{-1}$ juice at $75^{\text {th }}$ day of storage.
Ascorbic acid content of guava-pineapple based blended RTS beverages decreased with the advancement of storage period because of the fact that ascorbic acid being sensitive to oxygen, light and heat and was easily oxidized in presence of oxygen by both enzymatic and non-enzymatic catalyst and also it might have been destroyed during processing and subsequently during storage.

Similar results about the changes of ascorbic acid in juice was reported by Pathak et al., (2012) and found that there was a significant and continuous decline in ascorbic acid during entire period of storage in litchi and pomegranate blended RTS and nectar beverage. The gradual decrease in ascorbic acid content of juice was also found by Byanna and Gowda (2013) during standardization of sweet orange and kokum blended RTS beverage.

Table.1 Changes in TSS ( ${ }^{\circ}$ Brix) and total sugar (\%) content of blended guava and pineapple RTS beverage during storage

\begin{tabular}{|c|c|c|c|c|c|c|c|}
\hline Treatments & Day 0 & Day 15 & Day 30 & Day 45 & Day 60 & Day 75 & Average \\
\hline \multicolumn{8}{|l|}{ TSS ( ${ }^{\circ}$ Brix) } \\
\hline $\mathrm{T}_{1}(100 \%)$ & 13.83 & 14.07 & 14.35 & 14.61 & 14.70 & 14.77 & 14.39 \\
\hline $\left.\mathrm{T}_{2} 90: 10\right)$ & 14.12 & 14.18 & 14.41 & 14.57 & 14.78 & 14.85 & 14.48 \\
\hline $\mathrm{T}_{3}(80: 20)$ & 14.25 & 14.31 & 14.54 & 14.60 & 14.82 & 15.02 & 14.59 \\
\hline $\mathrm{T}_{4}(70: 30)$ & 14.62 & 14.68 & 15.08 & 15.29 & 15.43 & 15.48 & 15.09 \\
\hline $\mathrm{T}_{5}(60: 40)$ & 14.81 & 15.12 & 15.22 & 15.40 & 15.56 & 15.61 & 15.29 \\
\hline $\mathrm{T}_{6}(50: 50)$ & 15.06 & 15.31 & 15.53 & 15.70 & 15.81 & 15.81 & 15.54 \\
\hline S.Em ( \pm$)$ & 0.072 & 0.108 & 0.076 & 0.070 & 0.053 & 0.051 & - \\
\hline C.D. $(P=0.05)$ & 0.216 & 0.322 & 0.226 & 0.209 & 0.159 & 0.153 & - \\
\hline \multicolumn{8}{|l|}{ Total sugar $(\%)$} \\
\hline $\mathrm{T}_{1}(100 \%)$ & 6.47 & 6.64 & 6.91 & 7.27 & 7.48 & 7.53 & 7.05 \\
\hline $\left.\mathrm{T}_{2} 90: 10\right)$ & 6.72 & 6.93 & 7.22 & 7.56 & 7.72 & 7.80 & 7.32 \\
\hline $\mathrm{T}_{3}(80: 20)$ & 7.40 & 7.69 & 7.80 & 8.11 & 8.37 & 8.39 & 7.96 \\
\hline $\mathrm{T}_{4}(70: 30)$ & 7.86 & 8.19 & 8.30 & 8.34 & 8.41 & 8.41 & 8.25 \\
\hline $\mathrm{T}_{5}(60: 40)$ & 8.01 & 8.11 & 8.37 & 8.40 & 8.51 & 8.50 & 8.32 \\
\hline $\mathrm{T}_{6}(50: 50)$ & 8.25 & 8.43 & 8.70 & 8.75 & 8.87 & 8.88 & 8.65 \\
\hline S.Em ( \pm ) & 0.054 & 0.034 & 0.033 & 0.023 & 0.031 & 0.047 & - \\
\hline C.D. $(P=0.05)$ & 0.162 & 0.102 & 0.098 & 0.070 & 0.092 & 0.140 & - \\
\hline
\end{tabular}


Table. 2 Changes in acidity (\%) and ascorbic acid ( $\mathrm{mg} / 100 \mathrm{ml}$ of juice) content of blended guava and pineapple RTS beverage during storage

\begin{tabular}{|c|c|c|c|c|c|c|c|}
\hline Treatments & Day 0 & Day 15 & Day 30 & Day 45 & Day 60 & Day 75 & Average \\
\hline \multicolumn{8}{|l|}{ Acidity (\%) } \\
\hline $\mathrm{T}_{1}(100 \%)$ & 0.378 & 0.359 & 0.348 & 0.329 & 0.317 & 0.317 & 0.341 \\
\hline $\left.\mathrm{T}_{2} 90: 10\right)$ & 0.375 & 0.355 & 0.345 & 0.325 & 0.315 & 0.276 & 0.332 \\
\hline $\mathrm{T}_{3}(80: 20)$ & 0.365 & 0.346 & 0.337 & 0.315 & 0.284 & 0.279 & 0.321 \\
\hline $\mathrm{T}_{4}(70: 30)$ & 0.363 & 0.341 & 0.332 & 0.314 & 0.292 & 0.280 & 0.320 \\
\hline $\mathrm{T}_{5}(60: 40)$ & 0.361 & 0.341 & 0.325 & 0.307 & 0.294 & 0.275 & 0.317 \\
\hline $\mathrm{T}_{6}(50: 50)$ & 0.368 & 0.340 & 0.329 & 0.309 & 0.293 & 0.260 & 0.316 \\
\hline $\operatorname{S.Em}( \pm)$ & 0.009 & 0.002 & 0.002 & 0.003 & 0.003 & 0.014 & - \\
\hline C.D. $(P=0.05)$ & NS & 0.005 & 0.006 & 0.009 & 0.011 & NS & - \\
\hline \multicolumn{8}{|c|}{ Ascorbic acid (mg/100ml of juice) content } \\
\hline $\mathrm{T}_{1}(100 \%)$ & 65.75 & 64.12 & 62.54 & 60.10 & 59.85 & 59.55 & 61.98 \\
\hline $\left.\mathrm{T}_{2} 90: 10\right)$ & 56.26 & 53.98 & 53.00 & 52.84 & 51.72 & 51.70 & 53.25 \\
\hline $\mathrm{T}_{3}(80: 20)$ & 50.06 & 48.78 & 48.50 & 47.77 & 45.90 & 45.70 & 47.78 \\
\hline $\mathrm{T}_{4}(70: 30)$ & 43.22 & 42.00 & 40.53 & 40.05 & 39.98 & 39.86 & 40.94 \\
\hline $\mathrm{T}_{5}(60: 40)$ & 39.12 & 37.98 & 36.25 & 36.20 & 35.50 & 34.90 & 36.66 \\
\hline $\mathrm{T}_{6}(50: 50)$ & 33.63 & 31.21 & 30.00 & 28.71 & 27.68 & 27.67 & 29.82 \\
\hline $\operatorname{S.Em}( \pm)$ & 0.581 & 0.259 & 0.616 & 0.086 & 0.070 & 0.084 & - \\
\hline C.D. $(P=0.05)$ & 1.725 & 0.770 & 1.831 & 0.257 & 0.210 & 0.251 & - \\
\hline
\end{tabular}

Table.3 Changes in $\mathrm{pH}$ and TSS/acid ratio of blended guava and pineapple

RTS beverage during storage

\begin{tabular}{|c|c|c|c|c|c|c|c|}
\hline Treatments & Day 0 & Day 15 & Day 30 & Day 45 & Day 60 & Day 75 & Average \\
\hline \multicolumn{8}{|l|}{$\mathrm{pH}$ of RTS } \\
\hline $\mathrm{T}_{1}(100 \%)$ & 2.63 & 2.71 & 2.78 & 2.85 & 3.14 & 3.16 & 2.87 \\
\hline $\left.\mathrm{T}_{2} 90: 10\right)$ & 2.89 & 3.08 & 3.14 & 3.23 & 3.30 & 3.38 & 3.17 \\
\hline $\mathrm{T}_{3}(80: 20)$ & 2.66 & 2.75 & 2.81 & 2.87 & 3.18 & 3.21 & 2.91 \\
\hline $\mathrm{T}_{4}(70: 30)$ & 2.88 & 2.95 & 2.99 & 3.03 & 3.12 & 3.19 & 3.02 \\
\hline $\mathrm{T}_{5}(60: 40)$ & 2.93 & 3.01 & 3.07 & 3.13 & 3.21 & 3.28 & 3.10 \\
\hline $\mathrm{T}_{6}(50: 50)$ & 3.08 & 3.16 & 3.25 & 3.33 & 3.38 & 3.45 & 3.27 \\
\hline $\operatorname{S.Em~}( \pm)$ & 0.065 & 0.329 & 0.097 & 0.041 & 0.042 & 0.375 & - \\
\hline C.D. $(P=0.05)$ & 0.195 & NS & 0.290 & 0.121 & 0.125 & NS & - \\
\hline \multicolumn{8}{|l|}{ TSS/acid ratio } \\
\hline $\mathrm{T}_{1}(100 \%)$ & 36.56 & 39.19 & 41.25 & 44.34 & 46.28 & 46.51 & 42.36 \\
\hline $\left.\mathrm{T}_{2} 90: 10\right)$ & 37.74 & 39.91 & 41.71 & 44.83 & 46.83 & 54.18 & 44.20 \\
\hline $\mathrm{T}_{3}(80: 20)$ & 39.03 & 41.35 & 43.09 & 46.36 & 52.12 & 54.28 & 46.04 \\
\hline $\mathrm{T}_{4}(70: 30)$ & 40.29 & 43.02 & 45.38 & 48.72 & 52.72 & 55.31 & 47.57 \\
\hline $\mathrm{T}_{5}(60: 40)$ & 41.06 & 44.26 & 46.74 & 50.11 & 52.82 & 58.02 & 48.84 \\
\hline $\mathrm{T}_{6}(50: 50)$ & 41.27 & 45.04 & 47.19 & 50.78 & 53.97 & 60.83 & 49.85 \\
\hline $\operatorname{S.Em}( \pm)$ & 1.068 & 0.371 & 0.359 & 0.496 & 0.603 & 2.879 & - \\
\hline C.D. $(P=0.05)$ & 3.173 & 1.103 & 1.067 & 1.473 & 1.792 & 8.550 & - \\
\hline
\end{tabular}


Table.4 Mean sensory scores obtained by blended guava and pineapple RTS beverage during storage

\begin{tabular}{|l|c|c|c|c|c|c|}
\hline \multicolumn{1}{|c|}{ Characteristics } & $\begin{array}{c}\mathrm{T}_{1} \\
(100 \%)\end{array}$ & $\begin{array}{c}\mathrm{T}_{2} \\
(90: 10)\end{array}$ & $\begin{array}{c}\mathrm{T}_{3} \\
(80: 20)\end{array}$ & $\begin{array}{c}\mathrm{T}_{4} \\
(70: 30)\end{array}$ & $\begin{array}{c}\mathrm{T}_{5} \\
(60: 40)\end{array}$ & $\begin{array}{c}\mathrm{T}_{6} \\
(50: 50)\end{array}$ \\
\hline Taste & 5.73 & 6.15 & 6.98 & 7.11 & 7.74 & 7.22 \\
\hline Appearance & 6.76 & 7.00 & 7.09 & 7.33 & 7.70 & 7.77 \\
\hline Flavour & 6.10 & 6.58 & 7.07 & 7.42 & 7.80 & 7.53 \\
\hline Over all acceptability & 6.19 & 6.57 & 7.04 & 7.28 & 7.74 & 7.51 \\
\hline
\end{tabular}

All the treatments showed a significant increase in $\mathrm{pH}$ of fruit juice throughout storage period. Among different treatments, the average highest $\mathrm{pH}$ in juice was noticed in $\mathrm{T}_{6}$ (3.27). There was a significant increase in $\mathrm{pH}$ throughout storage except the storage at day of 15 and day of 75 that showed a nonsignificant result in $\mathrm{pH}$. Islam et al., (2014) also found in the experiment of different ratio of pineapple and orange juice with gradual decrease in titratable acidity and vitamin-C along the storage period and increment of TSS and progressiveness of $\mathrm{pH}$ during storage period.

There was a significant increase in TSS/Acid ratio during storage period in all the treatments from the initial average of $\mathrm{T}_{1}$ (36.56), $\mathrm{T}_{2}$ (37.74), $\mathrm{T}_{3}$ (39.03), $\mathrm{T}_{4}$ (40.29), $\mathrm{T}_{5}$ (41.06) and $\mathrm{T}_{6}$ (41.27) with final increase during storage was $\mathrm{T}_{1}(46.51), \mathrm{T} 2(54.18), \mathrm{T}_{3}$ (54.28), $\mathrm{T}_{4}$ (55.31), $\mathrm{T}_{5}(58.02)$ and $\mathrm{T}_{6}(60.83)$. The increase in the TSS/Acid ratio might be due to increased TSS and decreased acidity during storage by the conversion of oligosaccharides into sugars. The similar results were also reported by Shaheel et al., (2015) with karonda juice blended with guava, papaya and pineapple juices in different proportions through increasing of TSS, TSS/Acid ratio and total sugars with increase in storage period.

Organoleptic evaluation is generally the final guide of the quality from the consumer's point of view. In the experiment, results indicated that taste, appearance, flavour and overall acceptability of juice blends gradually decreased with the advancement of storage period. The ratio of $60 \%$ guava pulp and $40 \%$ pineapple juice $\left(\mathrm{T}_{5}\right)$ reached the highest sensory characters regarding flavour (7.80), taste (7.74) and overall acceptability (7.74) out of 9 point hedonic scale. The appearance which gradually decreased with storage perio might be due to break down of pigments and oxidative loss of pigments. Similar findings were reported by Deka et al., (2005) showing a gradual decrease in sensory quality on the RTS beverage prepared from dashehari mango and kew pineapple over six month storage. Decrease in overall acceptability scores in bael-aonla RTS during storage because of declining in colour, taste and flavour by six month storage was also reported by Singh et al., (2015).

Particularly in the blended beverage more emphasis is given on the basis of the consumer satisfaction and overall acceptability. So in the present study, it was concluded that the combination of $60 \%$ guava pulp and $40 \%$ pineapple juice was the best blended ratio

\section{References}

Amerine, M.A., Pangbron, R.M. and Rossler, E.A. 1965. Principles of sensory evaluation of food, Academic Press, New York and London.

Anonymous. 1984. A.O.A.C. Official 
methods of analysis, Association of Official Analytical Chemist $15^{\text {th }}$ Edn. Washington, D.C.

Byanna, C.N. and Gowda, I.N.D. 2013. Standardization of recipe for sweet orange and kokum blended RTS beverage preparation and storage. International Journal of Agricultural Sciences 9(2): 561-566.

Deka, B. C., Sethi, V. and Saikia, A. 2005. Changes in quality of mango-pineapple spiced beverage during storage. Indian Journal of Horticulture 62(1): 71-75.

Islam, M.A., Ahmad, I., Ahmed, S. and Sarker, A. 2014. Biochemical Composition and Shelf Life Study of Mixed Fruit Juice from Orange \& Pineapple. Journal of Environmental Sciences and Natural Resources 7(1): 227-232.

Kumar, S. and Godara, R. K. 2011. Preparation of RTS from aonla-guava blend and its storage studies. Annals of Biology 27(2): 163-166

Pathak. S, Pandey. A. and Gupta A. 2012. Change in quality parameter of blended beverages (RTS + Nectar) during storage. Environment and Ecology 30(4): 1226-1228.

Patil, R.M., Chikkasubbanna, V., Thipaana and Prashanth S J. 2014. Physicochemical character, sensory quality and storage behavior of rose apple RTS blended with Jamun. International Journal of Processing and Post Harvest Technology 5(1): 71-75.

Salari, H. Sreenivas, K.N., Krishna, H.C., Shankarappa, T.H. and Ramakrishna, B.M. 2012. Standardization of recipe for muskmelon blended beverages. Journal of Interacademicia 16(4): 87886.

Shaheel, S.K., Swami, D.V., Prasanna, B. and Krishna1, K.U. 2015. Effect of Storage period on chemical properties of RTS prepared from Karonda (Carissa carandas L.) blended juices. Plant Archives 15(1): 35-40.

Sindumathi, G.I. and Premalatha, M. R. 2013. Development and Storage Studies of Naturally Flavored Papaya-Pineapple Blended Ready to Serve (RTS) Beverages. International Journal of Science and Research (IJSR) 4: 438.

Singh, O., Singh, R. and Singh, P. 2015. Studies on quality evaluation of baelaonla ready to serve (RTS) drink during storage. The Asian Journal of Horticulture 10(1): 181-183.

Srivastava, R.P. and Kumar, S. 1998. Fruit and vegetable preservation, Principles and Practices: $2^{\text {nd }}$ Ed. International Book distributing co. pp.175-179.

\section{How to cite this article:}

Animesh Sarkar and Jimi Bulo. 2017. Standardization of Blending of Guava Pulp with Pineapple Juice for Preparation of Ready-To-Serve (RTS). Int.J.Curr.Microbiol.App.Sci. 6(11): 395-401. doi: https://doi.org/10.20546/ijcmas.2017.611.045 